\title{
Treatment of hyperfunctioning thyroid nodules by percutaneous ethanol injection
}

\author{
Bagher Larijani*1, Mohammad Pajouhi ${ }^{1}$, Hossein Ghanaati ${ }^{2}$, Mohammad- \\ Hassan Bastanhagh ${ }^{1}$, Fereshteh Abbasvandi ${ }^{1}$, Kazem Firooznia ${ }^{2}$, \\ Mahmood Shirzad1', Mohammad-Reza Amini1, Maryam Sarai1, \\ Nasreen Abbasvandi ${ }^{1}$ and Reza Baradar-Jalili ${ }^{1}$
}

Address: ${ }^{1}$ Endocrinology \& Metabolism Research Centre, Tehran University of Medical Sciences, Tehran, Iran and ${ }^{2}$ Medical Imaging Centre, Imam Khomeini University Hospital, Tehran, Iran

E-mail: Bagher Larijani* - emrc@sina.tums.ac.ir; Mohammad Pajouhi - emrc@sina.tums.ac.ir; Hossein Ghanaati - emrc@sina.tums.ac.ir; Mohammad-Hassan Bastanhagh - emrc@sina.tums.ac.ir; Fereshteh Abbasvandi - emrc@sina.tums.ac.ir;

Kazem Firooznia - emrc@sina.tums.ac.ir; Mahmood Shirzad - emrc@sina.tums.ac.ir; Mohammad-Reza Amini - emrc@sina.tums.ac.ir; Maryam Sarai - emrc@sina.tums.ac.ir; Nasreen Abbasvandi - emrc@sina.tums.ac.ir; Reza Baradar-Jalili - emrc@sina.tums.ac.ir

${ }^{*}$ Corresponding author

Published: 6 December 2002

BMC Endocrine Disorders 2002, 2:3

This article is available from: http://www.biomedcentral.com//472-6823/2/3

(C) 2002 Larijani et al; licensee BioMed Central Ltd. This is an Open Access article: verbatim copying and redistribution of this article are permitted in all media for any purpose, provided this notice is preserved along with the article's original URL.

Keywords: Hot Thyroid Nodules, Treatment, Ethanol, Thyrotoxicosis, Ultrasonography

\begin{abstract}
Background: Autonomous thyroid nodules can be treated by a variety of methods. We assessed the efficacy of percutaneous ethanol injection in treating autonomous thyroid nodules.

Methods: 35 patients diagnosed by technetium- 99 scanning with hyperfunctioning nodules and suppressed sensitive TSH (sTSH) were given sterile ethanol injections under ultrasound guidance. 29 patients had clinical and biochemical hyperthyroidism. The other 6 had sub-clinical hyperthyroidism with suppressed sTSH levels $(<0.24 \mu \mathrm{lU} / \mathrm{ml})$ and normal thyroid hormone levels. Ethanol injections were performed once every $\mathrm{I}-4$ weeks. Ethanol injections were stopped when serum $\mathrm{T}_{3}, \mathrm{~T}_{4}$ and sTSH levels had returned to normal, or else injections could no longer be performed because significant side effects. Patients were followed up at 3, 6 and, in 15 patients, 24 months after the last injection.
\end{abstract}

Results: Average pre-treatment nodule volume [ $18.2 \pm 12.7 \mathrm{ml}]$ decreased to $5.7 \pm 4.6 \mathrm{ml}$ at 6 months follow-up $[\mathrm{P}<0.00 \mathrm{I}]$. All patients had normal thyroid hormone levels at 3 and 6 months follow-up $[P<0.00$ I relative to baseline]. sTSH levels increased from $0.09 \pm 0.02 \mu \mathrm{lU} / \mathrm{ml}$ to $0.65 \pm$ $0.8 \mu \mathrm{lU} / \mathrm{ml}$ at the end of therapy $[\mathrm{P}<0.05]$. Only 3 patients had persistent sTSH suppression at 6 months post-therapy. $T_{4}$ and sTSH did not change significantly between 6 months and 2 years $[P>$ 0.05]. Ethanol injections were well tolerated by the patients, with only 2 cases of transient dysphonia.

Conclusion: Our findings indicate that ethanol injection is an alternative to surgery or radioactive iodine in the treatment of autonomous thyroid nodules. 


\section{Background}

Conventional therapy for hyperfunctioning thyroid nodules includes radioactive iodine, surgery, and long-term pharmacotherapy $[1,2]$. Radioactive iodine therapy is accompanied by a $10-40 \%$ risk of hypothyroidism [1-3]. A third option, introduced over the past twelve years, has been percutaneous ethanol injection (PEI) [4-19]. This method was first used in the treatment of hepatic adenomas and, subsequently, thyroid nodules $[4,5,8]$. It is particularly suitable for patients who are not candidates for surgery or radioiodine therapy. The tissues inside the nodule undergo fibrosis following ethanol injection [6]. The present study aims to evaluate the outcome and complications of PEI therapy for hyperfunctioning nodules. No study of this type and size has so far been carried out in Iran, a country with a significant prevalence of thyroid disorders and, until recently, an endemic goitre region.

\section{Methods \\ Patients}

This is a prospective study of the efficacy of percutaneous ethanol injection in a consecutive series of patients with a hyperfunctioning thyroid nodule. Patients meeting entry criteria were enrolled in the study and then followed up at specific times following completion of therapy. Entry criteria were a dominant hyperfunctioning thyroid nodule, as determined by technetium-99 scanning, a suppressed sensitive TSH (sTSH), and negative thyroid aspiration cytology. Patients on methimazole had their medication gradually tapered during the second and third PEI sessions, and discontinued before completion of therapy. Complete response was defined as normalisation of thyroid function tests and absence of clinical symptoms. Written informed consent was obtained from every patient. The study was approved by the relevant institutional review committee.

\section{Thyroid Function Tests}

Thyroid function tests were measured by second-generation radioimmunoassay (Kavoshyar, Tehran, Iran), and sTSH by immunoradiometric assay (same manufacturer), with intra- and inter-assay coefficients of variation for $\mathrm{T}_{3}$ of $3.3 \%$ and $7.5 \%$, for $\mathrm{T}_{4}$ of $6.8 \%$ and $8.0 \%$, and for $\mathrm{TSH}$ of 5.8 and 4.9 percent. The normal ranges were $\mathrm{T} 3=80-$ $230 \mathrm{ng} / \mathrm{dl}, \mathrm{T} 4=4.5-12.8 \mu \mathrm{g} / \mathrm{ml}$, and TSH $=0.2-5 \mu \mathrm{IU} / \mathrm{ml}$.

\section{Imaging}

Nodule volume was calculated automatically by the ultrasound machine, using the formula: length $\times$ width $\times$ thickness $\times \pi / 6$, which provides an approximation to the volume of a spheroid, and is reported to be $80-85 \%$ accurate [7].

\section{Nodule Cytology}

Every patient underwent a fine needle aspiration biopsy to rule out malignancy. In patients with multinodular goitre, the dominant nodule, as reported by ${ }^{99} \mathrm{Tm}$ scanning, was aspirated. In the single patient with two co-dominant nodules, both nodules were aspirated. The cytology report for every specimen was cystic colloid goitre, consisting of abundant colloidal material, with many haemosiderinladen macrophages and scanty follicular cells, dispersed throughout the specimen or else forming a loose honeycomb monolayer of cells. The distinction between the latter entity and follicular neoplasia, a source of diagnostic confusion when FNA is performed in patients with a hot nodule, where the aspirate is commonly highly cellular, was, in our samples, quite clear.

\section{Ethanol Injection}

The dimensions and volume of the nodules were measured by linear real-time ultrasonography, using a General Electric Sonochrome machine, with an $8 \mathrm{MHz}$ probe. Under direct ultrasound guidance, $0.5-10 \mathrm{ml}$ of sterile $95 \%$ ethanol (Pasteur Institute Production Centre - Tehran, Iran) was injected inside each nodule $(0.1 \mathrm{ml}$ per $\mathrm{ml}$ nodule volume, using a disposable plastic syringe and 22gauge needle). Two patients had cystic nodules, which were drained completely before administration of PEI. The injection needle was kept in place for 1-2 minutes in order to avoid any ethanol leakage, and patients were advised to take oral analgesia before injection. Injections were performed once every 1-2 weeks. Patients were assessed at the end of the treatment cycle and at 3 and 6 months afterwards. Thyroid function tests were performed on 15 patients at the end of 2 years. Thyroid function tests were performed after 3-4 rounds of injection. When hormone levels were found to be within the normal range, PEI therapy was deemed successful and the injections, discontinued.

\section{Statistical Analysis}

The repeated measures and paired-t tests were used to compare baseline and follow-up values, and Pearson's correlation test to measure the strength of the linear relationship between initial nodule size and reduction in nodule volume. Complete response was defined as a reduction in both nodule size and thyroid hormone levels, and normalization of sTSH levels.

\section{Results}

\section{Demographics}

35 patients (30 women, 5 men) aged $16-70$ years (mean age \pm SD: $38.6 \pm 12.4$ ) received PEI therapy. 18 patients (54\%) had solitary hyperfunctioning nodules on ${ }^{99} \mathrm{Tc}$ scanning, with complete suppression of the remaining thyroid tissue. 16 patients (46\%) had multinodular goitre with a dominant hyperfunctioning nodule. 1 patient had 
Table I: Pre- and post-pei thyroid function in 35 patients with hot nodules

Initial Assessment and Follow-up

\begin{tabular}{cccccc}
\hline & Before PEI $(n=35)$ & After PEI $(n=35)$ & 3 months $(n=35)$ & 6 months $(n=35)$ & 2 years $(n=15)$ \\
\hline & & & & & \\
T3 & $270.6 \pm 99.6$ & $169.05 \pm 58.3^{*}$ & $164.5 \pm 52.5^{*}$ & $157.6 \pm 46.7^{*}$ & $189.2 \pm 61.7^{*}$ \\
T4 & $14.9 \pm 4.6$ & $9.6 \pm 3.04^{*}$ & $9.9+2.8^{*}$ & $9.4+2.4^{*}$ & $10.2 \pm 2.46 \ddagger$ \\
TSH & $0.09 \pm 0.02$ & $0.65 \pm 0.8^{\dagger}$ & $0.62 \pm 0.8^{\dagger}$ & $0.71 \pm 0.8^{\dagger}$ & $0.86 \pm 1.5^{\dagger}$ \\
NV $(\mathrm{ml})$ & $18.2 \pm 12.7$ & $7.5 \pm 5.3$ & - & $5.7 \pm 4.6$ & - \\
TTV $(\mathrm{ml})$ & - & - & - & - & - \\
\end{tabular}

Normal Ranges: T3 $=80-230 \mathrm{ng} / \mathrm{dl} \mathrm{T} 4=4.5-12.8 \mu \mathrm{g} / \mathrm{ml} \mathrm{TSH}=0.2-5 \mu \mathrm{IU} / \mathrm{ml}$ Legend: $*$ Significant change $[\mathrm{P}<0.00 \mathrm{I}]$ compared to pre-treatment †Significant change $[\mathrm{P}<0.05]$ compared to pre-treatment $\ddagger$ No significant change $[\mathrm{P}>0.05]$ compared to follow-up at 6 months Abbreviations: NV: nodule volume TTV: total thyroid volume PEl: percutaneous ethanol injection

two hot nodules. 29 patients (82.9\%) were hyperthyroid (suppressed sTSH and elevated $\mathrm{T}_{3}$ and $\mathrm{T}_{4}$ levels), and 6 patients $(17.1 \%)$ had sub-clinical hyperthyroidism with sTSH suppression and normal levels of thyroid hormones.

\section{Nodule Size}

Mean pre-treatment volume in the 36 nodules was $18.2 \pm$ $12.7 \mathrm{ml}$ (range $=4-44 \mathrm{ml}$ ). Mean post-PEI nodule volume decreased to $7.5 \pm 5.3 \mathrm{ml}$ (range $=1-21 \mathrm{ml}$ ), reaching 5.7 $\pm 4.6 \mathrm{ml}$ (range $0.5-20 \mathrm{ml}$ ) at 6 months follow-up $[\mathrm{P}<$ $0.001]$. Average volume reduction was $12.48 \pm 10.6 \mathrm{ml}$, with a linear correlation between initial nodule volume and the magnitude of volume reduction: the greater the initial nodule volume, the greater the reduction in nodule volume $[\mathrm{r}=0.94, \mathrm{P}=0.007]$.

\section{Thyroid Function Tests}

Sensitive TSH levels were suppressed in every patient before start of therapy, with a mean level of $0.09 \pm 0.02 \mu \mathrm{IU} /$ $\mathrm{ml}$. In the sub-clinical hyperthyroid group, sTSH had risen to a mean of $0.42 \pm 0.47 \mu \mathrm{IU} / \mathrm{ml}$ by the end of treatment, with 3 out of 6 patients still having sTSH levels below the normal range. At 3 months, the mean sTSH level in this group increased to $1.18 \pm 1.3 \mu \mathrm{IU} / \mathrm{ml}$, with only 1 patient showing persistent TSH suppression. At 6-months follow up, sTSH levels had normalised in all 6 patients, with a mean sTSH level of $1.15 \pm 0.97 \mu \mathrm{IU} / \mathrm{ml}[\mathrm{P}=0.04]$.

In the hyperthyroid group, mean sTSH concentration at the end of therapy had risen to $0.69 \pm 0.9 \mu \mathrm{IU} / \mathrm{ml}[\mathrm{P}=$ 0.02]. Of the 9 hyperthyroid patients (31.0\% of the hyperthyroid group) whose sTSH levels had not shown a satisfactory response to PEI therapy, only 3 patients $(10.3 \%)$ had suppressed TSH at 6 months follow-up. By the end of therapy, all patients were clinically asymptomatic, with normal levels of T3 and T4 $[\mathrm{P}<0.001]$. The success rate for PEI was $91.4 \%$, with only 3 patients $(8.6 \%)$ exhibiting
Table 2: Complications of Therapy in 35 Patients with Hot Nodules Treated by Percutaneous Ethanol Injection

\begin{tabular}{cc}
\hline Complication & Number of patients \\
\hline Pain/burning at site of injection & 35 \\
Neck pain & 12 \\
Mandibular pain & 12 \\
Dizziness/vertigo & 12 \\
Pyrexia & 3 \\
Transient dysphonia & 2 \\
Bruising at site of injection & 2 \\
Cough & 1 \\
\end{tabular}

persistent sTSH suppression with normal peripheral thyroid hormone levels. These three patients all had solitary hot nodules. Two were women, aged 37 and 25, and the third was a 44 year-old man.

\section{Complications}

No lasting or serious complication was observed with PEI therapy. 2 cases of transient dysphonia were reported. Both patients recovered completely. Examination by an ENT specialist showed transient vocal cord paralysis and subsequent full recovery. Table 2 shows the number of patients experiencing complications during treatment. All complications improved within minutes, except for $2 \mathrm{ep}-$ isodes of fever, which persisted for 24-48 hours, and 2 cases of transient dysphonia, which resolved fully after 1 week and 6 months.

\section{Discussion}

Hyperfunctioning thyroid nodules are common, yet there is controversy about their management $[1,2,21]$. The different modalities used include surgery, radioiodine, and 
percutaneous ethanol injection $[1,22]$. The studies carried out over the past decade on the efficacy of PEI in the treatment of autonomous thyroid nodules indicate that it is effective, requires no anaesthesia, and carries minimal risk $[19,23]$. In our study, PEI also proved to be an effective treatment for patients with hyperfunctioning thyroid nodules and either clinical or sub-clinical hyperthyroidism. None of our patients reported symptoms of hyperthyroidism after PEI and all of them achieved normal peripheral thyroid hormone levels. At 3 months follow-up, only 3 patients showed persistent sTSH suppression in spite of normal thyroid hormone levels. Reduction in the volume of nodules was significant at 3 months $[\mathrm{P}<0.001]$, with an average value of $12.48 \pm 10.6 \mathrm{ml}$ per nodule. The success rate for this study $(91.3 \%)$ is consistent with that reported elsewhere (54-100\%) [18,19,23,25]. Two large studies from Italy, one on 132 patients followed up over 8.5 years [23] and the other on 117 patients followed up over 5 years [24], suggest that PEI be recommended as treatment for hyperfunctioning thyroid adenoma with sub-clinical hyperthyroidism. The success rate in our patients is higher, however, than that reported in a number of larger series, notably that reported by Lippi et al [24], in which the overall success rate was $45.9 \%$ at 3 months, increasing to $73.9 \%$ at one year. 99 Tm scans were only performed before treatment in our patients; follow-up scanning may well have reduced our success rate too.

PEI can also be recommended as alternative therapy in patients at high-risk for surgery (even when the nodules are large) or for patients in whom radioactive iodine may have relative contraindication(s) $[2,18,25,27]$. Many authors further stress that PEI should only be carried out in centres thoroughly familiar with the technique required [28-31]. Transient dysphonia (spontaneous recovery over a period of weeks or months) has been reported in 2-5\% of cases $[20,30,32]$. The pathology in every case has been either direct chemical injury to the recurrent laryngeal nerves, secondary to alcohol leakage outside the nodule, or nerve injury due to a sudden elevation in pressure inside the nodule. Two cases of transient vocal cord paralysis were seen in our patients; one recovered fully after 1 week, the other fully after 6 months. Real-time ultrasound used to monitor the PEI procedure can identify ethanol leakage, which shows up as a hyperechogenic area, as it is happening. One group has suggested that, in order to minimise the risk involved, a bolus of $2 \%$ Xylocaine $(0.2-$ $0.5 \mathrm{ml}$ ) should be injected first in order to mark the injection path before PEI itself is begun [9]. We omitted this approach because the nodules were all clearly identifiable by ultrasound and there was little risk of leakage. Studies have shown that ethanol produces coagulative necrosis of nodular tissue through hemorrhagic infarction and vascular thrombosis $[33,34]$. Furthermore, in the area of viable tissue surrounding the zone of biochemical ablation, en- zyme activity is reduced. The areas of necrotic thyroid parenchyma are clearly distinguishable from the seemingly normal thyroid tissue surrounding them, which is free of any evidence of inflammation $[33,34]$. The probability of recurrence is virtually eliminated once granulation scar tissue replaces the nodule. Hypothyroidism is not observed even after prolonged follow-up [26,35]. Recurrence of hyperthyroidism has not been reported in patients who have had a complete response to PEI [26,35]. Our study confirms this. It should be noted that a number of our patients had multinodular goitre, with more than one hot nodule being detected on radioisotope scanning. In experienced hands, major complications of PEI, such as fibrosis of adjacent tissues or thrombogenesis within the large vessels of the neck, are unlikely [33]. $\mathrm{T}_{3}$ and $\mathrm{T}_{4}$ levels in both pre-toxic and toxic patients decreased significantly [P $<0.001]$, and sTSH levels increased significantly, in response to PEI $[\mathrm{P}<0.01]$. The most important factors in predicting response to PEI are initial nodule volume and the level of skill possessed by the physician performing the procedure. Significant nodule shrinkage following PEI has already been reported in the literature [36]. Our findings confirm this. There exists a direct linear relationship between reduction in nodule volume and initial nodule volume $(\mathrm{r}=0.94, \mathrm{p}=0.007)$, that is to say the greater the initial size of the nodule, the larger the reduction in size.

PEI is also effective in non-toxic thyroid nodules in young patients $[6,36]$. However, since the conversion rate for non-toxic nodules (to toxic nodules) is $1.2-5.7$ percent/ year depending on the follow-up series [37,38], many authors recommend conservative therapy for patients with non-toxic hot nodules. Furthermore, given that long-term sub-clinical hyperthyroidism is associated with increased bone turnover and accelerated bone demineralisation, and that in patients with concomitant heart disease, the increased quantity of hormone secreted by an autonomous nodule may produce arrhythmias or lead to cardiac failure, treatment of hyperfunctioning nodules with suppressed sTSH becomes necessary and PEI may be a reasonable alternative in some cases $[1,2,14,36,39]$.

\section{Conclusions}

We conclude that PEI is a method that is relatively inexpensive and does not require bed rest or hospitalisation. It combines convenience with avoidance of surgical risks and hypothyroidism associated with radioiodine therapy. PEI is a more practical option in younger patients because it leaves no residual surgical scar, involves no exposure to radiation, is not associated with a long-term risk of hypothyroidism, and leads to a reduction in nodule volume without recourse to surgery.

\section{Competing interests}

None declared 


\section{Authors' contributions}

$\mathrm{BL}, \mathrm{MP}$ and MHB conceived and designed the study, and drafted the original and revised drafts of the article. FA, NA, MS and MS recruited patients and performed the initial and follow-up clinical evaluations. HG and KF carried out the ultrasound examinations and ethanol injections. MRA and RBJ carried out the data analysis.

\section{All authors read and approved the final manuscript.}

\section{Acknowledgements}

The authors would like to thank Vahab Fatourechi, M.D., of the Mayo Clinic for his critical review of the paper, Ms. Michelle K. Papaconstandinou, of the same institution, for her secretarial support, as well as Mohammad Tavangar, M.D., of the Department of Pathology, Dr Shariati Hospital, for his expert guidance.

\section{References}

I. David E, Rosen IB, Bain J, James J, Kirsh JC: Management of the Hot Thyroid Nodule. Am J Surg 1995, 170:48I-3

2. Giuffrida $D$, Gharib $\mathrm{H}$ : Controversies in the Management of Cold, Hot, and Occult Thyroid Nodules. Am J Med 1995, 99:642-50

3. Zingrillo M, Torlontano M, Ghiggi MR, et al: Radioiodine and Percutaneous Ethanol Injection in the Treatment of Large Toxic Thyroid Nodules: A Long-Term Study. Thyroid 2000, 10:985

4. Livraghi T, Paracchi A, Ferrari C, et al: Treatment of Autonomous Thyroid Nodules with Percutaneous Ethanol Injection: Preliminary Results [Work In Progress]. Radiology 1990, 175:827-9

5. Monzani F, Goletti O, De Negri F, et al: Autonomous Thyroid Nodule and Percutaneous Ethanol Injection. Lancet 1991, 337:743

6. Martino E, Murtas ML, Loviselli A, et al: Percutaneous Intranodular Ethanol Injection for Treatment of Autonomously Functioning Thyroid Nodules. Surgery 1992, I I 2: I I6I-5

7. Brunn J, Block U, Ruf G, et al: Accuracy of the clinical assessment of thyroid size. Dan Med Bull I99I, 38:87

8. Goletti O, Monzani F, Caraccio N, et al: Percutaneous Ethanol Injection Treatment of Autonomously Functioning Single Thyroid Nodules: Optimisation of Treatment and Short-Term Outcome. World j Surg 1992, 16:784-90

9. Paracchi A, Ferrari C, Livraghi T, et al: Percutaneous Intranodular Ethanol Injection: A New Treatment for Autonomous Thyroid Adenoma. I Endocrinol lnvest 15:353-62

10. Mazzeo S, Toni MG, De Gaudio C, et al: Percutaneous Injection of Ethanol to Treat Autonomous Thyroid Nodules. AJR Am J Roentgenol 1992, 161:87|-6

II. Papini E, Panunzi C, Pacella CM, et al: Percutaneous UltrasoundGuided Ethanol Injection: A New Treatment of Toxic Autonomously Functioning Thyroid Nodules? J Clin Endocrinol Metab 1993, 76:4II-6

12. Monzani F, Del Guerra P, Caraccio N, et al: Percutaneous Ethanol Injection Therapy of Autonomous Nodule and AmiodaroneInduced Thyrotoxicosis. Thyroidology 1994, 6:99-102

13. Livraghi T, Paracchi A, Ferrari C, et al: Treatment of Autonomous Thyroid Nodules with Percutaneous Ethanol Injection: 4Year Experience. Radiology 1994, 190:529-33

14. Di Lelio A, Rivolta M, Casati M, Capra M: Treatment of Autonomous Thyroid Nodules: Value of Percutaneous Ethanol Injection. AJR Am J Roentgenol 1995, 164:207-13

15. Nakada K, Katoh C, Kanegae K, et al: Percutaneous Ethanol Injection Therapy for Autonomously Functioning Thyroid Nodule. Ann Nucl Med 1996, I0: 17I-6

16. Mincheva L, Simeonov S, Troev D, et al: Percutaneous Ethanol Sclerotherapy of Autonomous Thyroid Nodules: Preliminary Results. Folia Med 1997, 39:49-54

17. Komorowski J, Kuzdak K, Pomorski L, Bartos M, Stepien H: Percutaneous Ethanol Injection in Treatment of Benign NonFunctional and Hyperfunctional Thyroid Nodules. Cytobios 1998, 95:143-50
18. Solbiati L, Lerace T, Cova L, Dellanoce M, Marelli P: Percutaneous Ethanol Injection of Autonomously Functioning Thyroid Nodule. Rays 1999, 24:348-57

19. Tarantino L, Giorgio A, Mariniello N, et al: Percutaneous Ethanol Injection of Large Autonomous Hyperfunctioning Thyroid Nodules. Radiology 2000, 214:143-8

20. Brkljacic B, Sucic M, Bozikov V, Hauser M, Hebrang A: Treatment of Autonomous and Toxic Thyroid Adenomas By Percutaneous Ultrasound-Guided Ethanol Injection. Acta Radiologica 200 I, 42:477-8I

21. Eyre-Brook La, Talbot $\mathrm{CH}$ : The Treatment of Autonomous Functioning Thyroid Nodules. Br J Surg 1982, 69:577-9

22. Ferrari C, Reschini E, Paracchi A: Treatment of the Autonomous Thyroid Nodule: A Review. Eur J Endocrinol 1996, I35:383-90

23. Monzani F, Caraccio N, Goletti O, et al: Treatment of Hyperfunctioning Thyroid Nodules with Percutaneous Ethanol Injection: Eight Years' Experience. Exp Clin Endocrinol Diabetes 1998, 106:S54-8

24. Lippi F, Ferrari C, Manetti L, Rago T, Santini F, Monzani F, et al: Treatment of Solitary Autonomous Thyroid Nodules by Percutaneous Ethanol Injection: Results of an Italian Multicenter Study. J Clin Endocrinol Metab 1996, 8 I (9):326I-64

25. Caraccio N, Goletti O, Lippolis PV, et al: Is Percutaneous Ethanol Injection a Useful Alternative for the Treatment of the Cold Benign Thyroid Nodule? Five Years' Experience. Thyroid 1997, 7:699-704

26. Monzani F, Caraccio N, Goletti O, et al: Five-Year Follow-Up of Percutaneous Ethanol Injection for the Treatment of Hyperfunctioning Thyroid Nodules: A Study of I 17 Patients. Clin Endocrinol (Oxf) 1997, 46:9-15

27. Zingrillo M, Torlontano M, Chiarella R, et al: Percutaneous Ethanol Injection may be a Definitive Treatment for Symptomatic Thyroid Cystic Nodules Not Treatable by Surgery: FiveYear Follow-Up Study. Thyroid 1999, 9:763-7

28. Spiezia S, Cerbone G, Assanti AP, et al: Power Doppler Ultrasonographic Assistance in Percutaneous Ethanol Injection of Autonomously Functioning Thyroid Nodules. J Ultrasound Med 2000, 19:39-46

29. Cerbone G, Spiezia S, Colao A, et al: Percutaneous Ethanol Injection Under Power Doppler Ultrasound Assistance in the Treatment of Autonomously Functioning Thyroid Nodules. I Endocrinol lnvest 1999, 22:752-9

30. Schumm-Draeger PM: Ultrasound-Guided Percutaneous Ethanol Injection in the Treatment of Autonomous Thyroid Nodules: A Review. Exp Clin Endocrinol Diabetes 1998, 106:S59-62

31. Verde G, Papini E, Pacella CM, et al: Ultrasound-Guided Percutaneous Ethanol Injection in the Treatment of Cystic Thyroid Nodules. Clin Endocrinol (Oxf) 1994, 41:719-24

32. Papini E, Pacella CM, Verde G: Percutaneous Ethanol Injection (PEI): What is its Role in the Treatment of Benign Thyroid Nodules? Thyroid 1995, 5:147-50

33. Monzani F, Caraccio N, Basolo F, et al: Surgical and Pathological Changes After Percutaneous Ethanol Injection Therapy of Thyroid Nodules. Thyroid 2000, 10:1087-92

34. Miccoli P, Bendinelli C, Monzani F: Surgical Aspects of Thyroid Nodules Previously Treated by Ethanol Injection. Exp Clin Endocrinol Diabetes 1998, 106:S75-7

35. Janowitz P, Ackmann S: [Long-Term Results of UltrasoundGuided Ethanol Injections in Patients with Autonomous Thyroid Nodules and Hyperthyroidism]. Med Klin 200I, 96:45I-6

36. Monzani F, Goletti O, Caraccio N, et al: Percutaneous Ethanol Injection Treatment of Autonomous Thyroid Adenoma: Hormonal and Clinical Evaluation. Clin Endocrinol (Oxf) 1992, 36:49 I7

37. Thomas CG Jr, Croom RD: Current Management of the Patient with Autonomously Functioning Nodular Goitre. Surg Clin North Am 1987, 67:315-28

38. Kunori T, Shinya H, Satomi T, et al: Management of Nodular Goitres and their Operative Indications. Surg Today 2000, 30:722-6

39. Mann K: Evaluation of Risk in Autonomously Functioning Thyroid Nodules. Exp Clin Endocrinol Diabetes 1998, 106:S23-6

40. Zbranca E, Mogos V, Vulpoi C, et al: [Fine Needle Puncture Method of Treatment in Nodular Pathology of the Thyroid]. Ann Endocrinol 1996, 57:433-7 
41. Goletti O, Monzani F, Lenziardi M, et al: Cold Thyroid Nodules: A New Application of Percutaneous Ethanol Injection Treatment. J Clin Ultrasound 1994, 22:175-8

\section{Pre-publication history}

The pre-publication history for this paper can be accessed here:

http://www.biomedcentral.com/1472-6823/2/3/prepub

Publish with Biomed Central and every scientist can read your work free of charge

"BioMed Central will be the most significant development for disseminating the results of biomedical research in our lifetime. "

Sir Paul Nurse, Cancer Research UK

Your research papers will be:

- available free of charge to the entire biomedical community

- peer reviewed and published immediately upon acceptance

- cited in PubMed and archived on PubMed Central

- yours - you keep the copyright

Submit your manuscript here:

http://www.biomedcentral.com/info/publishing_adv.asp
BioMedcentral 